\section{Genetic links for scattered Jews}

Rehovot

PRELIMINARY studies using DNA sequences as a new and sophisticated tool for genetic analysis tend to support the conclusion drawn from earlier investigations that the Jews, even after being scattered around the world for two millennia, remain - to a significant degree - genetically distinctive.

This view, propounded for many years by Professor Batsheva Bonné-Tamir from the Department of Human Genetics at Tel Aviv University's Sackler School of Medicine, has met with opposition from some other scientists who use different statistical methods and from those who feel that any attempt to suggest the existence of a specific Jewish group is to be rejected as racist doctrine. Professor Bonné-Tamir is obviously not a proponent of such a doctrine, nor does she suggest that the Jews are better or worse for having a common genetic heritage. She simply points to the evidence that it exists.

Among the genetic markers used in the past by Professor Bonné-Tamir are blood types, enzymes, serum proteins and histocompatibility antigens (see American Journal of Human Genetics 34, 50; 1982). The new data, which have been submitted for publication, come from the most direct genetic measure - that of DNA sequences, in this case of short stretches of mitochondrial DNA. But whatever the criterion, she and Professor Samuel Karlin of Stanford University in the United States find that Jews from Iraq, for example, have far more in common from a genetic viewpoint with Jews from Poland than either group has with the non-Jews among whom they have lived for centuries. This is also true of immigrants to Israel from such diverse areas as Germany and the Soviet Union on the one hand and Libya on the other.

It has become possible to make more revealing comparisons between Jews and non-Jews in recent years because of the increasing number of genetic studies on both.

There are, it seems, a few exceptions to the general picture of relative Jewish distinctiveness. Jews from Yemen, often popularly regarded as the Jewish group that looks most "biblical", are a case in point. "They have a genetic make-up", BonnéTamir reports, "that is characteristic of the Saudi-Arabian peninsula and are probably the descendants of indigenous tribes which converted to Judaism in the fourth and fifth centuries."

A similar situation prevails in regard to Cochin Jews and the local Kerala Indians, communities that are genetically linked to one another but have little in common, from a genetic viewpoint, with other Oriental-Jewish groups or with non-Jewish elements in southwest Asia. This fits in well, Professor Bonné-Tamir points out, with the theory proposed by Professor
Avinoam Adam of Everyman's University (Israel's equivalent of the UK Open University), who has written: "in some areas and during some specific periods, the Jewish religion expanded much faster than Jewish genes".

Most timely of all, in view of the present wave of immigration from Ethiopia, are her findings about the Jews from that country. Various theories exist as to their origins, with members of the community itself tending to argue that they are descen-

\section{Canberra}

As soon as the Organization for Economic Cooperation and Development (OECD) draft report on the state of Australian science and technology was made available last month, it became obvious that many of the recommendations for improvement were exactly the opposite of those in operation at present or likely in the near future. The examiners asserted that it was essential that the science and technology portfolios be combined and represented at Cabinet level by a strong minister. An Australian federal election was held between the first draft of the report and its submission to the Australian authorities, the upshot of which was a portfolio reshuffle, splitting Mr Barry Jones's Department of Science and Technology, with politically important policy sections being absorbed by Senator John Button's Department of Industry and Commerce (see Nature 5 January, p.4). Mr Jones's remaining Department of Science has in the meantime been casting about for new vistas in science without technology, a condition described by the examiners as "perverse", because, in their view, the topics are so completely interwined. The government's action also puts paid to the examiners' recommendation that the Australian Science and Technology Council (ASTEC) should report to a "strong science minister" rather than supply policy advice directly to the Prime Minister, which has been its brief since 1976 .

The difficulty is the notion of a single strong minister for science and technology. Senator Button certainly fills the bill for his now-extended Department of Industry, Technology and Commerce, but part of the reason for the political downgrading of $\mathrm{Mr}$ Jones's portfolio was his unwillingness to linger in smoke-filled rooms where the deals are done. It is difficult for citizens of nations where science and technology are not (yet) an issue to appreciate the job of advocacy that $\mathrm{Mr}$ Jones has done in Australia, and the void that existed before him. The examiners noted that many of the depositions submitted to them in the course dants of the tribe of Dan (one of the original 12 tribes of the Bible) and/or of ancient Jewish communities in Upper Egypt that moved south. Yet after studying representatives of a hundred immigrant families from Ethiopia, Professor Bonné-Tamir comes to the conclusion that genetically they most resemble the Amhara tribe, and to a lesser extent the Billen and Tigre tribes, of Ethiopia. But she says "there is no denying the fact that the Yemenite, Cochin and Ethiopian Jews have long displayed strong emotional bonds with Judaism and rushed to join their co-religionists in Israel as soon as they had the opportunity to do so."

Nechemia Meyers

\title{
OECD begs leave to differ
}

of the study bore witness to the discussions he had sparked in 1983-84, but something else shone through as well: a sense that science and technology were somehow external to national life and that the transition from research to design and sales of a product seemed to involve the collision of mutually uncomprehending cultures.

Part of this they attributed to the education system and recommended (inter alia) that research in universities and other tertiary institutions be strengthened, especially by the purchase of modern equipment, both propositions unlikely in the short run, given the Treasury's present parsimonious mood. The examiners supported some tactics - such as manpower planning - that are unlikely to find favour, and suggested that Australia should not follow blindly the example of other countries in developing "key technologies" such as information technology and biotechnology, but instead examine its own latent strengths on a sectoral basis, sugge ting pharmaceuticals as a possible new industry. Whereas in the past Australia has used bounties and tariffs to shore up industry rather than the system of fiscal incentives common in other OECD countries which encourages business enterprise to classify its activities as research and development for tax purposes, the examiners recommended that tax-based schemes be instituted in Australia, a strategy the government has already begun and may expand.

Although preceded by an OECD rapporteur a year ago, the examiners themselves spent only one week in Australia. Inevitably, their report must be coloured by views expressed in the submissions made to them. They seem awake, nonetheless, to the pressures that have been brought to bear on OECD referees in the past, noting that familiar arguments about the economic benefits of investment in intellectual and technological infrastructure may be needed for the benefit of the Commonwealth Department of Finance. A final consultation and draft are due later this year. 